\title{
The relationship between corporate social responsibility and financial performance through the mediating role of corporate image: Evidence from Egyptian hotel industry
}

\author{
Ibrahim A. Elshaer \\ Lecturer of Strategic Business Management, Faculty of Tourism and Hotels, \\ Suez Canal University
}

\begin{abstract}
Corporate social responsibility (CSR) can be understood as a company's voluntary activities "that appear to further some social good, beyond the interests of the firm and that which is required by law". Examples include reducing the environmentally hazardous materials, the creation of products integrating social attributes, and support for local businesses. The relationships between corporate social responsibility (CSR) and financial performance (FP) have been extensively reviewed and tested in the management literature, but their results are widely varied. Scholars disaccord on the link between (CSR) and (FP); whether it is a positive, negative, curvilinear, or even there is no link at all. It has therefore been recommended that this relationship (CSR and FP) should be tested further within a particular context and that mediating and moderating variables should be taken into account for further examination of this link. This study tested the link between CSR and financial (FP) performance through the mediating role of corporate image in the Egyptian hotel industry using structural equation modeling as the main data analysis technique to provide a more clear explanation of how some CSR practices may be more beneficial than others, to organization performance through the mediating role of corporate image.
\end{abstract}

Keywords: corporate social responsibility, corporate image, financial performance, hotel industry, structural equation modeling

\section{Introduction}

For more than 70 years corporate social responsibility (CSR) has been extensively reviewed in the literature. In 1953 , Bowen (1953) wrote his book on Businessman's Social Responsibilities. Since then, the terminology of business social responsibility has been changed to CSR. The World Business Council for Sustainable Development (WBCSD) proposed one of the commonly adopted definitions of CSR. It states that 'CSR is the continuing commitment by business to behave ethically and contribute to economic development while improving the quality of life of the workforce and their families as well as the local community and society at large' (WBCSD, 1999).

The relationships between corporate social responsibility (CSR) and financial performance (FP) have been extensively reviewed and tested in the management literature, but their results are widely varied. Scholars have found a positive, a negative, curvilinear, and even no effect of CSR on FP (McWilliams and Siegel, 2000; Hillman and Keim, 2001; Bhattacharya and Sen, 2004; Barnett and Salomon, 2006; Wu, 2006). More specific, some authors (Vance, 1975; Aupperle et al., 1985) argued that social responsibility is costly, and puts companies at an economic disadvantage in comparison to less socially responsible firms.

Another group of papers found no association between investments in socially responsible activities and market value (e.g., Hamilton et al., 1993; Diltz, 1995a,b; Guerard, 1996; Kurtz and diBartolomeo, 1996; Reyes and Grieb, 1998; Statman, 2000; Baue et al., 2005). In contrast to the studies cited above; several papers find social responsibility is associated with returns that are above market averages for the periods studied (Luck and Pilotte,1993; Diltz et al., 1999; Schueth, 2003).

It has therefore been recommended that this relationship (CSR and FP) should be tested further within a particular context (Chand, 2006) and that mediating and moderating variables should be taken into account for further examination of this link (Rowley and Berman, 2013). This study responded to the previous calls and tested the link between CSR and financial performance (FP) through the mediating role of corporate image in the Egyptian hotel industry. Two models were tested in Structure equation modeling using AMOS statistical software, testing both direct and indirect relationships between CSR and FP through the mediating role of corporate image.

\section{Literature review}

\section{Corporate social responsibility}

Corporate social responsibility includes 'achieving commercial success in ways that honor ethical values and respect people, communities, and the natural environment' (Clark, 2006; Porter \& Kramer, 2006). The European Commission (2010) introduced a definition of corporate social responsibility as 'a concept whereby companies integrate social and environmental concerns in their business operations and in their interaction with their stakeholders on a voluntary basis'. Another definition in the management literature was introduced by Davis (1973, p. 312), who defines CSR as 'the firm's considerations of, and response to, issues beyond the narrow economic, technical, and legal requirements of the firm to accomplish social [and environmental] benefits along with the traditional economic gains which the firm 
seeks'. There is no universally definition of CSR, but some commonalities between the definitions of CSR could be found. Of these; CSR is the obligation of the organization to stakeholder, CSR is business activities beyond the organization's technical or economic interest (McWilliams \& Siegel, 2001), CSR is the commitment to act ethically (Watts and Holme, 1999), CSR should contribute to economic improvements (Verschoor, 2005), CSR should develop life of the workforce and local society (Redford, 2005), and CSR should decrease environmental impacts (Deephouse,1996). In tourism industry, although the literature on CSR in this sector is scarce, it recently attracted great attention (Kang, Lee, \& Huh, 2010). Research has been increasingly focused on cost reduction and resource consumption in hospitality (Ayuso, 2006; Bohdanowicz \& Zientara, 2009). Additionally, a larger number of organizations are integrating the concept of CSR into their business, with the purpose of enhancing the environment, the quality of life in local society, or the welfare of their own employees (Bohdanowicz \& Zientara, 2009; Font et al., 2012).

To be more specific, the hotel sector is one of the world's fastest growing industries that plays a predominant role in tourism, as tourists usually travel to different locations, in large numbers. It is often recognized as a source of both economic and social benefits through supporting job creation, leisure and business travel, and the sharing of experiences and knowledge (De Grosbios, 2012). On the other hand, hotel industry also enacts several negative influences on social, natural, and economic environment; including the impact on climate change, air and noise pollution, waste creation, besides other economic and social issues. Furthermore, several hotels stand in the main cities neighboring even cultural or natural heritage places; so attract large number of tourists, which in turn resulted in growing ecological footprint (Kirk, 1995). Ranging from small to large organizations, hotels and resorts consume water, energy, food, linen, paper, laundry, stationery cleaning materials, consumables, and other resources, produce water, air, noise, and soil pollution, and affects the local societies through their occupation of own spaces, use of infrastructure, and relationships with local government (Chung and Parker, 2010). The previous debate of the inter-correlation between hotels industry and CSR concept, encourage several hotel to provide CSR related reports. While reporting CSR practices does not necessarily match the actual CSR activities, it is clear that CSR is becoming a well-known global initiative (Holcomb, Upchurch, \& Okumus, 2007).

Hilton Corporation has the most comprehensive CSR reporting, followed by Marriot in the second category, and the Accor hotel group came in the third category. Most hotel corporations can enhance their CSR reporting and hotel companies should "live up to their reputation of being 'hospitable' not only to their guests but also to society" (Holcomb, Upchurch, \& Okumus, 2007).

\section{Corporate social responsibility, financial performance, and corporate image}

Carrige and Mele (2004) classified the theories and its related approaches of CSR in four groups: (1) instrumental theories, in which organizations main aim is to gain more profit, and its social practices are only a means to attain economic results; (2) political theories, which concern themselves with the corporations power in society and employing this power in the political arena; (3) integrative theories, in which the corporation main interest is the satisfaction of social demands; and (4) ethical theories, based on ethical responsibilities of organizations to community (See table 1).

The current study is mainly interested in the first group of theories, which considers CSR a means to attain profit. In this group of theories, CSR is viewed only as a tool to obtain some economic objectives. A representative of this view is Friedman (1970) who stated that 'the only one responsibility of business towards society is the maximization of profits to the shareholders within the legal framework and the ethical custom of the country'. In concern to obtaining profits; it does not exclude taking into consideration the requirements of all others who have a stake in the firm (stakeholders). It has been contended that in some conditions the satisfaction of these requirements can contribute to maximizing the shareholder value (Mitchell et al., 1997; Odgen and Watson, 1999).

In the same vein (The first group of theories), CSR can be viewed as a source to improve financial performance, and generate competitive advantage either (Husted or Allen, 2000). Additionally, CSR can be the main element to improve the organization's image and reputation. In a way, it tries to generate product differentiation by forming socially responsible practices that can affect company's reputation (Smith and Higgins, 2000). As McWilliams and Siegel (2001) have pointed out: 'support of cause-related marketing creates a reputation that a firm is reliable and honest. Consumers typically assume that the products of a reliable and honest firm will be of high quality'.

Several empirical studies are conducted to test the previous theoretical assumptions (the relationship between CSR and FP); however, the finding of these studies report mixed results. More specific, some authors found social responsibility is costly, and puts companies at an economic disadvantage such as Wood (1991), Vance (1975), Aupperle et al., (1985), and Ho Kang et al., (2010). Another group of authors found no relationship between investments in socially responsible activities and financial returns such as Hamilton et al., (1993), Diltz (1995), Guerard (1996), Reyes and Grieb (1998), Statman( 2000), and Baue et al., (2005). In contrast to the previous studies; several authors confirmed that social responsibility can directly improve the corporate financial performance (Luck and Pilotte, 1993; Diltz et al., 1999; Schueth, 2003; Inoue and Lee, 2011; Lee et al., 2013; Mustafa et al., 2012; Tamajón and Aulet, 
2013). Therefore, it has been recommended that this relationship (CSR and FP) should be tested further within a particular context (Chand, 2006), besides, mediating and moderating variables should be taken into account for further examination of this link (Rowley and Berman, 2013). The current study tested the link between CSR and financial performance through the mediating role of corporate image in the Egyptian hotel industry.

\section{Research framework and hypotheses}

A conceptual framework is a structure of concepts and/or theories which are pulled together as a map for the study. A conceptual framework is a fundamental part of a quantitative research study; explains the research questions or hypotheses, whereas, in a qualitative study, it may be less important or less clear in its structure ( Collis and Hussey, 2003; Punch,2005). In the current study, and if the data analysis (exploratory factor analysis) give an evidence that CSR is a uni-dimensional construct, two models will be suggested as shown in figure 1. Model 1 shows the direct relationship between CSR (as a uni-dimensional construct) with financial performance. Therefore, the below hypothesis will be proposed

H1: CSR (as a uni-dimensional construct) has a positive direct relationship with financial performance

The second model tests the indirect relationship of CSR with FP with the full mediation role of corporate image. Therefore, the below hypothesis will be proposed:

H 1: CSR has a positive relationship with corporate image

H 2: Corporate image has a positive relationship with FP

H 3: CSR has a positive relationship with FP through corporate image

However, if the data analysis (exploratory factor analysis) gives evidence that CSR is multidimensional construct; then two different models will be tested further with different hypotheses show the direct and indirect relationships of the unlike dimensions of CSR with FP as shown in figure 2 and 3.

\section{Figure 1: The research framework}
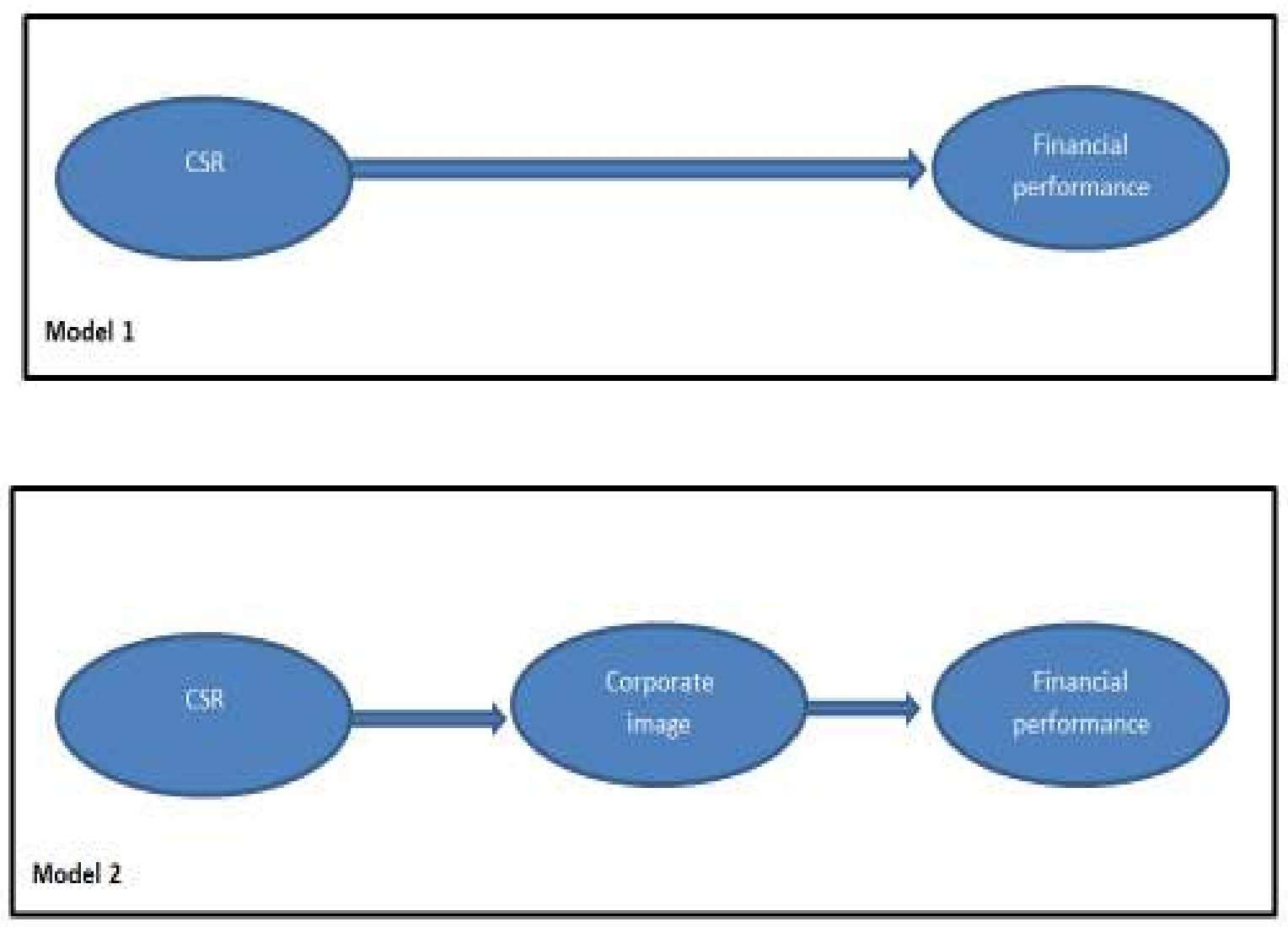
Table 1: Corporate social responsibilities theories and related approaches

\begin{tabular}{|c|c|c|c|}
\hline Types of theory & Some key Approaches & Short description & Reference \\
\hline \multirow{3}{*}{$\begin{array}{l}\text { Instrumental theories } \\
\text { (focusing on achieving } \\
\text { economic } \\
\text { objectives through social } \\
\text { activities) }\end{array}$} & Maximization of shareholder value & Long-term value maximization & Friedman (1970), Jensen (2000) \\
\hline & $\begin{array}{l}\text { Strategies for competitive } \\
\text { advantages }\end{array}$ & $\begin{array}{l}\text { - Social investments in a competitive context } \\
\text { - Strategies based on the natural resource view of the firm and the } \\
\text { dynamic capabilities of the firm } \\
\text {-Strategies for the bottom of the } \\
\text { economic pyramid }\end{array}$ & $\begin{array}{l}\text { Porter and Kramer (2002) } \\
\text { Hart (1995), Lizt (1996) }\end{array}$ \\
\hline & Cause-related marketing & $\begin{array}{l}\text { Altruistic activities socially recognized used as an instrument of } \\
\text { marketing }\end{array}$ & $\begin{array}{l}\text { Prahalad and Hammond (2002), Hart and } \\
\text { Christensen (2002),Prahalad (2003), Varadarajan } \\
\text { and Menon (1988), Murray and Montanari (1986 }\end{array}$ \\
\hline \multirow{3}{*}{$\begin{array}{l}\text { Political theories } \\
\text { (focusing on a responsible } \\
\text { use of business power } \\
\text { in the political arena) }\end{array}$} & Corporate constitutionalism & $\begin{array}{l}\text { Social responsibilities of businesses arise from the amount of } \\
\text { social power that they have }\end{array}$ & Davis $(1960,1967)$ \\
\hline & integrative Social Contract Theory & $\begin{array}{l}\text { Assumes that a social contract between business and society } \\
\text { exists }\end{array}$ & $\begin{array}{l}\text { Donaldson and Dunfee (1994, } \\
\text { 1999) }\end{array}$ \\
\hline & Corporate (or business) citizenship & $\begin{array}{l}\text { The firm is understood as being like a citizen with certain } \\
\text { involvement in the community }\end{array}$ & $\begin{array}{l}\text { Wood and Lodgson (2002), Andriof } \\
\text { and McIntosh (2001) }\end{array}$ \\
\hline \multirow{4}{*}{$\begin{array}{l}\text { Integrative theories } \\
\text { (focusing on the integration of } \\
\text { social demands) }\end{array}$} & Issues management & $\begin{array}{l}\text { Corporate processes of response to those social and political } \\
\text { issues which may impact significantly upon it }\end{array}$ & $\begin{array}{l}\text { Sethi (1975), Ackerman (1973), Jones (1980), } \\
\text { Vogel, (1986), Wartick and Mahon (1994) }\end{array}$ \\
\hline & Public responsibility & $\begin{array}{l}\text { Law and the existing public policy process are taken as a } \\
\text { reference for social performance }\end{array}$ & Preston and Post $(1975,1981)$ \\
\hline & Stakeholder management & Balances the interests of the stakeholders of the firm & $\begin{array}{l}\text { Mitchell et al. (1997), Agle and } \\
\text { Mitchell (1999), Rowley (1997) }\end{array}$ \\
\hline & Corporate social performance & $\begin{array}{l}\text { Searches for social legitimacy and } \\
\text { processes to give appropriate responses to social issues }\end{array}$ & $\begin{array}{l}\text { Carroll (1979), Wartick and } \\
\text { Cochran (1985), Wood (1991b) Swanson (1995) }\end{array}$ \\
\hline \multirow{4}{*}{$\begin{array}{l}\text { Ethical theories } \\
\text { (focusing on the right thing to } \\
\text { achieve a good society) }\end{array}$} & Stakeholder normative theory & $\begin{array}{l}\text { Considers fiduciary duties towards stakeholders of the firm. Its } \\
\text { application requires reference to some moral theory (Kantian, } \\
\text { Utilitarianism, theories of justice, etc.) }\end{array}$ & $\begin{array}{l}\text { Freeman (1984, 1994), Evan and Freeman } \\
\text { (1988), Donaldson and Preston (1995), Freeman } \\
\text { and Phillips (2002), Phillips et al. (2003) }\end{array}$ \\
\hline & Universal rights & $\begin{array}{l}\text { Frameworks based on human rights, } \\
\text { labor rights and respect for the environment }\end{array}$ & $\begin{array}{l}\text { The Global Sullivan Principles } \\
\text { (1999), UN Global Compact (1999) }\end{array}$ \\
\hline & Sustainable development & $\begin{array}{l}\text { Aimed at achieving human development considering present and } \\
\text { future generations }\end{array}$ & $\begin{array}{l}\text { World Commission on Environment and } \\
\text { Development (Brutland Report) (1987), Gladwin } \\
\text { and Kennelly (1995) }\end{array}$ \\
\hline & The common good & $\begin{array}{l}\text { Oriented towards the common } \\
\text { good of society }\end{array}$ & $\begin{array}{l}\text { Alford and Naughton (2002), Mele' } \\
\text { (2002) Kaku (1997) }\end{array}$ \\
\hline
\end{tabular}

Source: Carrige and Mele (2004: 63-64) 


\section{Operationalization of the study constructs}

There is a contradiction in the literature concerning the dimensional structure of CSR. Some authors such as Park and Lee (2009); Lee et al., (2013) identified several dimensions of the construct CSR and then a single composite score of CSR was used in the data analysis. In contrast, other scholars such as Clarkson (1995); Waddock \& Graves (1997); Godfrey \& Hatch (2007); and Mustafa et al., (2012), assumed CSR is a multidimensional construct. They predetermined several dimensions of CSR and investigate the impact of each single dimension with its potential outcomes including business performance. CSR's dimensional structure will be tested in the current studies, using exploratory factor analysis to find out if the proposed dimensions of CSR will be employed as a uni or a multidimension construct in the model that will test the relationship of CSR with corporate image and financial performance.

Turker (2009) introduced a widely accepted scale to measure CSR contains four dimensions (see table 2) as following:

First factor: including CSR to society, natural environment, future generations, and NGOs (7 indicators).

Second factor: including CSR to employees (5 indicators).

Third factor: including CSR to customers ( 3 indicators).

Fourth factor: including CSR to the government ( 2 indicators).

A 10-point numerical scale ranging from one (completely dissatisfied) to 10 (completely satisfied) was used. Three items were used to measure the hotel corporate image position (branding advantage) in the market (brand awareness, brand image, and brand personality) in comparison with its main direct competitors, drawing mainly from the study of Zou et al., (2003). A 10-point rating scale, ranging from (1) 'Much Worse' to (10) 'Much Better', to assess managers' perceptions about the image of their hotels.

Table (2): Turker (2009) scale to measure CSR

\begin{tabular}{|c|c|}
\hline Factors & Indicators \\
\hline $\begin{array}{l}\text { CSR to society, } \\
\text { natural environment, } \\
\text { future generations, } \\
\text { and NGOs }\end{array}$ & $\begin{array}{l}\text { - Our company contributes to campaigns and projects that promote the well- } \\
\text { being of the society. } \\
\text { - Our company implements special programs to minimize its negative impact on } \\
\text { the natural environment. } \\
\text { - Our company participates in activities which aim to protect and improve the } \\
\text { - } \text { Ouality of the natural environment. } \\
\text { - Our company targets sustainable growth which considers future generations. } \\
\text { - } \text { Oenerations. } \\
\text { - Our company encourages its employees to participate in voluntary activities. } \\
\text { Our company supports nongovernmental organizations working in problematic }\end{array}$ \\
\hline 2-CSR to employees & $\begin{array}{l}\text { - Our company supports employees who want to acquire additional education. } \\
\text { - Our company policies encourage the employees to develop their skills and } \\
\text { careers. } \\
\text { - Our company implements flexible policies to provide a good work \& life } \\
\text { balance for its employees. } \\
\text { - The management of our company is primarily concerned with employees' } \\
\text { needs and wants } \\
\text { The managerial decisions related with the employees are usually fair. }\end{array}$ \\
\hline 3-CSR to customers & $\begin{array}{l}\text { - Our company provides full and accurate information about its products to its } \\
\text { customers. } \\
\text { - } \quad \text { Our company respects consumer rights beyond the legal requirements. } \\
\text { - Customer satisfaction is highly important for our company. }\end{array}$ \\
\hline 4-CSR to government & $\begin{array}{l}\text { - } \quad \text { Our company always pays its taxes on a regular and continuing basis. } \\
\text { - } \quad \text { Our company complies with legal regulations completely and promptly. }\end{array}$ \\
\hline
\end{tabular}

Source: adopted from Turker (2009:419) 
While financial performance is frequently measured using subjective (perceptual) measures (e.g. Agus and Sagir, 2001; Douglas and Judge, 2001; Kaynak, 2003; Lakhal, 2005; Zu, 2008), financial performance is measured in this study using two objective indicators (employee productivity and revenue per room), as subjective measures typically contain systematic (biases) and random measurement errors (Bollen and Paxton, 1998).

\section{Methodology}

\section{Data collection}

In this study, data was obtained from a survey of 360 four and five-star hotels in Egypt to test the impact of CSR on FP. A total of 320 responses (130 from five-star hotels and 190 from four-star hotels) were obtained. Twenty uncompleted questionnaires were removed leaving 300 usable questionnaires and yielding a response rate of $83 \%$. All questionnaires were completed by the hotel general managers. The questionnaire was pre-tested through interviewing three academic researchers and 20 hotel managers. Some revisions to the questionnaire were made to improve its clarity and eliminate some duplicated items. The internal consistency (reliability) of the research variables were tested using Cronbach's alpha method, exploratory factor analysis (EFA) was employed to test the dimensionality of the research variables, and finally, structural equation modeling (SEM) was employed to test the research hypotheses.

\section{Results and Discussions Tests for dimensionality, and reliability}

Exploratory factor analysis (EFA) is employed in the current study to test the dimensionality structure of the study construct. EFA is a statistical approach used to achieve two main results; data summarizing and data reduction (Tabachnick and Fidell, 2007; Hair et al., 2006). Data summarizing aims to locate appropriate structure of the research variables under the specific logic factors (Tabachnick and Fidell, 2007; Hair et al., 2006). Data reduction is a process used to remove uncorrelated items and reduces the number of items within each variable (Tabachnick and Fidell, 2007; Pallant, 2007). All the necessary conditions (sample size, factorability of R (strength of the relationship among the variables), missing data, outliers, linearity, normality, and multicollinearity) for performing EFA are met.

All the indicators employed to measure CSR, corporate image, and financial performance were subjected to exploratory factor analysis (EFA) in SPSS v20 to find out how many factors (dimensions) they suggest. EFA produced a four-factor solution for CSR, and one-factor solution for corporate image, and one-factor solution for FP. All the items used in the questionnaire to measure CSR are retained and load highly on the expected factors (with no cross loading).

The current study measurements were evaluated for reliability by using Cronbach's alpha, which is an internal consistency method, based on the recommendation of Malhotra (2010). Cronbach's alpha is a technique that calculates the mean reliability coefficient for all possible ways of splitting a set of items into two halves (Malhotra, 2010). High alpha scores mean more internal reliability in the measurement scale whereas a low alpha indicates the items used do not really capture the construct and some items may have to be eliminated to improve the alpha level. However, according to Hair et al (2006), and Nunnally (1978) the lower limit for Cronbach's alpha is 0.70 . Bryman and Bell (2003) asserted the figure 0.080 is typically employed as a rule of thumb to denote an acceptable level of internal reliability.

Composite Cronbach Alpha values scores for all factors reflect satisfactory internal consistency for those items. The reliability scores of all averaged scales (Cronbach Alpha or $\alpha$ ) of all factors exceed 0.90, which is above the usual cut-off level of 0.7 as recommended by Nunnally and Bernstein (1994). Internal reliabilities of each construct (Cronbach's alpha) ranged from 0.83 to 0.95 , all exceeding the minimum criterion of 0.60 (Bagozzi and Yi, 1988).

\section{SEM Results and Interpretations}

Structural equation modeling was employed in the current study because this data analysis technique can test the causal direct and indirect relationship between the research variables (Byrne, 2010). Additionally, SEM is a technique to analyze multiple and interrelated relationships among the constructs for model building. It is the only analysis that allows complete and simultaneous tests of all relationships for the complex and multidimensional phenomenon (Tabachnic and Fidell, 2007:679). In addition, SEM allows representing a latent variable in the relationships between variable while taking into account the estimated measurement error related to the imperfect measurement of variable as well (Schumacker and Lomax, 2010). 
All necessary conditions to run SEM, i.e. conditions regarding the sample size, missing data, outliers, normality, and multicollinearity, were met. Several goodness-of-fit (GOF) measures were used to assess model fit: Chi-square $\left(\chi^{2}\right)$, Normed $\chi 2$ (CMIN/DF $<0.3$ ), Root Mean Square Error of Approximation ( RMSEA $\left.<0.05\right)$, Root Mean square Residual (SRMR<0.05), Normed Fit Index (NFI>0.90), Comparative Fit Index (CFI>0.90), TuckerLewis Index (TLI >0.90), Parsimony Comparative Fit Index (PCFI>0.50), and Parsimony Normed Fit Index (PNFI>0.50). All the models were specified and over identified; the data for the models was entered in AMOS v18 by using the ML estimation technique

Figure (2): Model 3 direct effect of CSR on FP

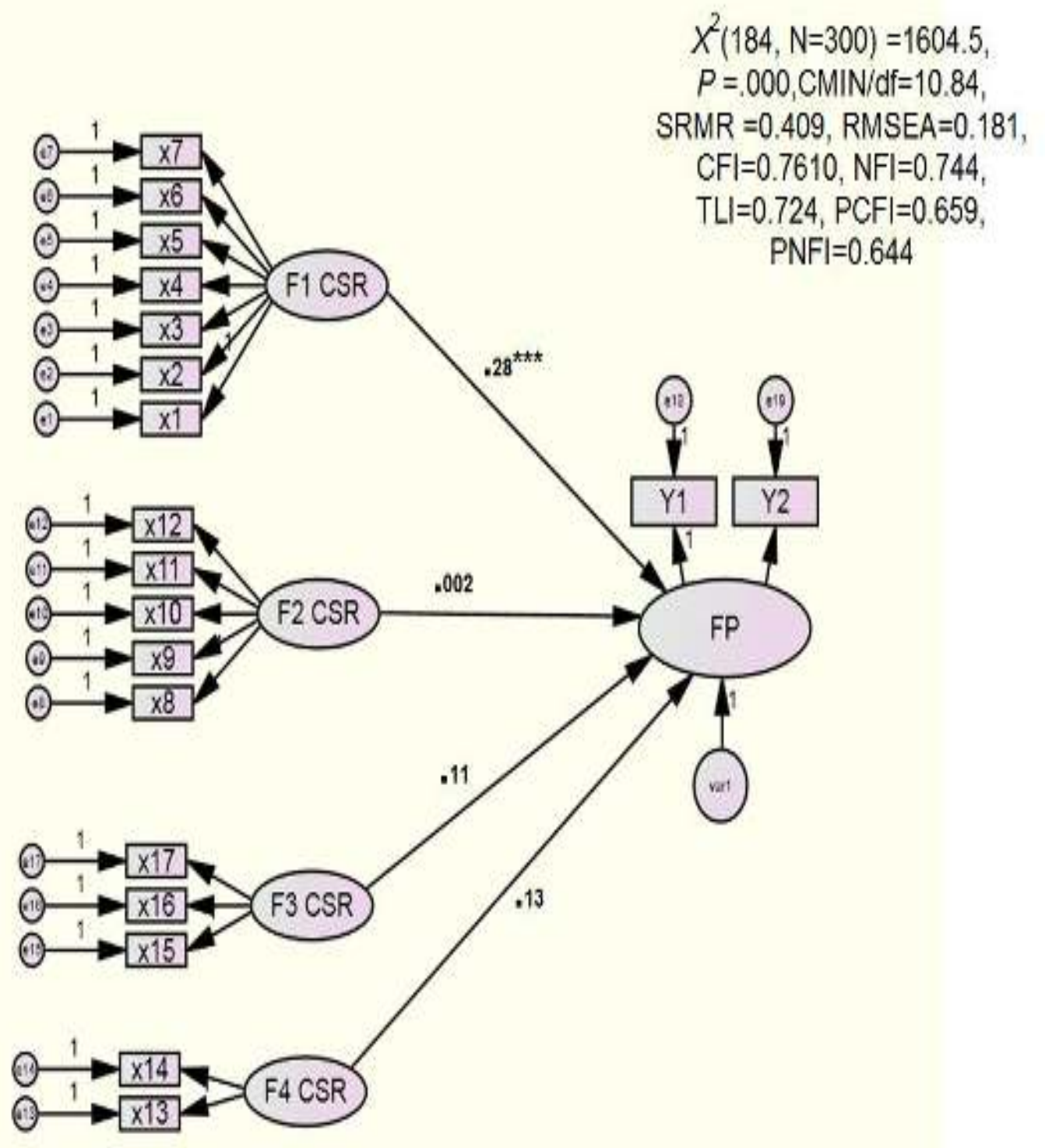

***Correlation is significant at the 0.00 level; F1 CSR, F2 CSR, F3 CSR, and F3 CSR: the four Factors that measuring corporate social responsibility; FP: financial performance; $\mathrm{x} 1-\mathrm{x} 14$ : the indicators that measuring CSR factors; Y1, and Y2: indicators that measure financial performance e1-e19: Measurement error associated with the observed variables. var1: Residual error in the prediction of an unobserved endogenous factor. 
Figure (3): Model 4 indirect effect of CSR on FP through corporate image

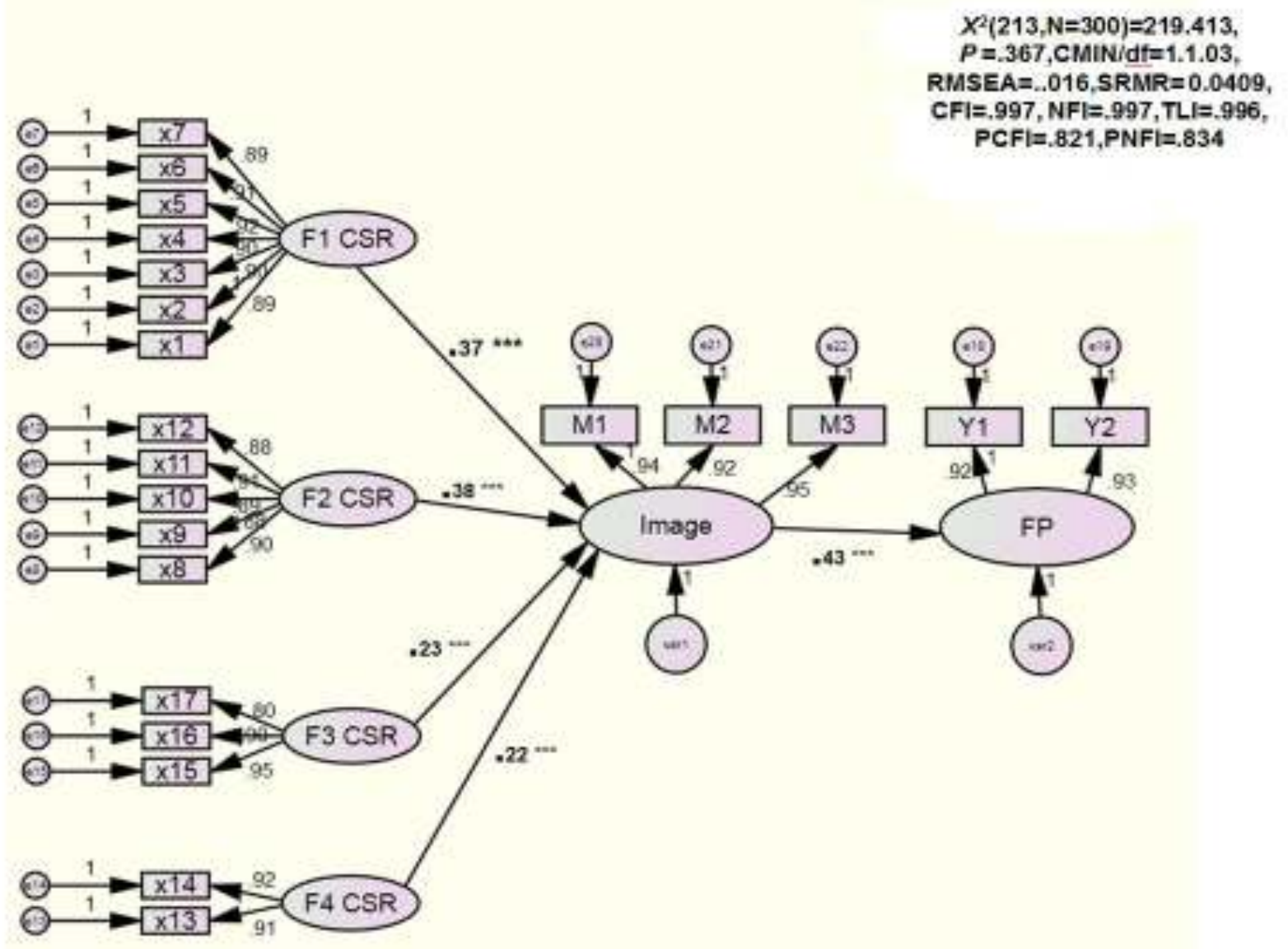

***Correlation is significant at the 0.00 level; F1 CSR, F2 CSR, F3 CSR, and F3 CSR: the four Factors that measuring corporate social responsibility; FP: financial performance; $x 1-x 14$ : the indicators that measuring CSR factors; M1-M3: indicators that measures corporate image; Y1, and Y2: indicators that measure financial performance e1-e22: Measurement error associated with the observed variables. Var1- var2: Residual error in the prediction of an unobserved endogenous factor.

The goodness of fit indices (GOF), as shown in table 3, indicate that model 3 (see figure 2) which test the direct effect of CSR on FP does not fit the data well, while model 4 (see figure 3) which test the effect of CSR on FP through the mediating role of corporate image perfectly fits the data. More specific, model 3 (direct relationships between CSR and FP) GOF indices indicate that the model does not fit the data well. In details model $3 \chi^{2}(184, \mathrm{~N}=$ $300)=1604.5, \mathrm{P}<0.001$ (Normed $\chi 2=10.84, \mathrm{RMSEA}=0.81, \mathrm{SRMR}=.409, \mathrm{CFI}=0.76, \mathrm{NFI}=0.74, \mathrm{TLI}=0.72$, $\mathrm{PCFI}=0.65$, and PNFI=0.64). Model 4 (indirect relationships between CSR on FP through corporate image) results indicate that the model GOF indices fit the data well. In details model $4 \chi^{2}(2413, \mathrm{~N}=300)=219.43, \mathrm{P}=.36$, Normed $\chi^{2}=1.03$ (below the cut of point of 3), RMSEA=0.016 (below the cut of point of .03 ), SRMR $=.046$ (below the cut of point of .03), CFI= 0.997, NFI=0.97, TLI=0.996 (all above the cut of point of .90), PCFI=0.821, and PNFI=0.834 (both above the cut of point of .5), (see table 3).

After obtaining satisfying results for the proposed model (model 4); the researcher tests the research hypotheses. Each path in the structural model between the latent variables represents a specific hypothesis. Hypotheses are usually tested in the form of a null hypothesis $\mathrm{H} 0$, where no relationship exists or estimate equals zero. The null hypotheses are either rejected or not rejected, depending on the significance level (P value) of the standardized coefficient of research parameters. If $\mathrm{P}$ value is less than the significant level (i.e. $\mathrm{P} \leq 0.05$ ), there is an evidence to reject the null hypothesis, and if the $\mathrm{P}$ value is greater than the significant level (i.e. $\mathrm{P}>0.05$ ), there is no evidence to reject the null hypothesis (Pallant, 2007). Significance levels employed in the current study are $\leq$ 
$0.05, \leq 0.01$ and $\leq 0.001$. The lower the significance level, the more the data must deviate from the null hypothesis (estimate equals zero). Therefore, the 0.001 level is more conservative than the 0.01 level. In this study, a significance level less than $\leq 0.05$ is considered acceptable, while $\leq 0.01$ is considered strong and $\leq 0.001$ is considered a high significance level.

Structural equation modeling using AMOS v18 is employed to test the null hypothesis (estimate equals zero) of these relationships (between the latent factors) as shown in Figure 2, and 3. Those relationships represent the likely direct and indirect relationships between CSR and financial performance. Table 4 presents selected output from AMOSv18 showing the hypotheses, standardized (estimates) regression weights, the P-value, and whether the null hypothesis is supported or rejected.

Since model 3 GOF indices does not fit the data well (see figure 2 and table 3), the hypotheses (in model 3 ) between CSR and FP will not be discussed in depth (see table 3). However, Model 4 (see figure 3) GOF indicates this model better fits the data and could further be used to explain the study hypotheses (see table 3 ).

In model four (see figure 3), which assumes CSR is a multidimensional construct contains four dimensions (CSR to society, natural environment, future generations, and NGOs; CSR to employees; CSR to customers; CSR to government) and investigates the indirect impacts of CSR on FP through the mediating role of corporate image, the path coefficient between F1 CSR (CSR to society, natural environment, future generations, NGOs) and corporate image is 0.37 with a high significance $\mathrm{P}$-value $(\mathrm{P}<0.001)$, which lead to the rejection of the null hypothesis and indicates that F1 CSR has a positive significant directly effects on corporate image. This result indicates, the corporate (hotel) image increases when the hotel contributes to campaigns and projects that promote the well-being of the society, implements special programs to minimize its negative impact on the natural environment, participates in activities aiming to protect and improve the quality of the natural environment, targets sustainable growth that considers future generations, makes investment to create a better life for future generations, encourages its employees to participate in voluntarily activities, and supports nongovernmental organizations working in problematic areas. This result is consistent with Robbins \& De Cenzo (2002), and Hayward (2005).

Moreover, the examination of the path coefficients and the related P-value to assess the effect of F2 CSR (CSR to employees) on the corporate image reveals that F2 CSR has a direct positive effect on the corporate image $(0.38 ; \mathrm{P}<0.001)$. This highly significant $(\mathrm{P}<0.001)$ path coefficient provide an evidence to reject the null hypothesis (no relationship exists) and indicates that F2 CSR has a positive direct effect on the corporate image. This result indicates that the corporate (hotel) image increases when the hotel supports employees who want to acquire additional education, encourage the employees to develop their skills and careers, implements flexible policies to provide a good work and life balance for its employees, management is primarily concerned with employees' needs, and managerial decisions related to the employees are usually fair. This is consistent with several previous studies results such as those conducted by Fombrun \& Shanley (1990, Riordan et al., (1997) and Bauman and Skitka (2012).

Table (3): Summary of model fit indices for the proposed research models

\begin{tabular}{|c|c|c|c|c|c|c|c|c|}
\hline & \multicolumn{3}{|c|}{$\begin{array}{c}\text { AFM } \\
\text { absolute fit measures }\end{array}$} & \multicolumn{3}{|c|}{$\begin{array}{c}\text { IFM } \\
\text { incremental fit measures }\end{array}$} & \multicolumn{2}{|c|}{$\begin{array}{c}\text { PFM } \\
\text { parsimony fit measures }\end{array}$} \\
\hline & $\chi^{2 / \mathrm{df}}$ & RMSEA & SRMR & CFI & NFI & TLI & PNFI & PCFI \\
\hline Standard fit values & $\leq 3$ & $\begin{array}{l}\leq 0.03 ; \leq \\
0.08\end{array}$ & $\begin{array}{l}\leq 0.03 \\
\leq 0.08\end{array}$ & $\geq 0.90$ & $\geq 0.90$ & $\geq 0.90$ & $>0.5$ & $>0.5$ \\
\hline $\begin{array}{l}\text { Model 3: } \\
\text { Direct impact of CSR on } \\
\text { FP }\end{array}$ & 10.84 & 0.181 & 0.409 & 0.76 & 0.744 & 0.724 & 0.64 & 0.65 \\
\hline $\begin{array}{l}\text { Model 4: } \\
\text { Indirect impact of CSR on } \\
\text { FP through corporate } \\
\text { image }\end{array}$ & 1.03 & .016 & .041 & .997 & .997 & .996 & .821 & .834 \\
\hline
\end{tabular}


Table (4): Hypothesized relationships, Standardised Regression Weights, P-values, and null hypotheses supported/rejected (CSR\&FP).

\begin{tabular}{|c|c|c|c|c|c|}
\hline & $\begin{array}{l}\text { Hypothesized } \\
\text { Relationships }\end{array}$ & $\begin{array}{l}\text { Standardized } \\
\text { estimate }\end{array}$ & $P$ & $\begin{array}{c}\text { Null } \\
\text { hypothesis } \\
\text { (estimate } \\
\text { equals zero) }\end{array}$ & interpretation \\
\hline \multicolumn{6}{|c|}{ Model 3} \\
\hline H1 & FP <--- F1 CSR & .28 & $* * *$ & Reject & $\begin{array}{l}\text { F1 CSR has a positive direct significant effect } \\
\text { on FP (effect size }=.28 \text { ) }\end{array}$ \\
\hline $\mathrm{H} 2$ & FP <--- F2 CSR & .002 & .65 & Fail to Reject & $\begin{array}{l}\text { The direct positive significant effect of F2 CSR } \\
\text { on FP is not supported (effect size }=.002 \text { ) }\end{array}$ \\
\hline H3 & FP <--- F3 CSR & .11 & .08 & Fail to Reject & $\begin{array}{l}\text { The direct positive significant effect of F3 CSR } \\
\text { on FP is not supported (effect size }=.11 \text { ) }\end{array}$ \\
\hline $\mathrm{H} 4$ & FP <--- F4 CSR & .13 & .06 & Fail to Reject & $\begin{array}{l}\text { The direct positive significant effect of F4 CSR } \\
\text { on FP is not supported (effect size }=.13 \text { ) }\end{array}$ \\
\hline \multicolumn{6}{|c|}{ Model 4} \\
\hline H1 & Image <- F1 CSR & .37 & $* * *$ & Reject & $\begin{array}{l}\text { F1 CSR has a positive direct significant effect } \\
\text { on corporate image (effect size }=.37 \text { ) }\end{array}$ \\
\hline $\mathrm{H} 2$ & Image <- F2 CSR & .38 & **** & Reject & $\begin{array}{l}\text { F2 CSR has a positive direct significant effect } \\
\text { on corporate image (effect size }=.38 \text { ) }\end{array}$ \\
\hline H3 & Image <- F3 CSR & .23 & $* * *$ & Reject & $\begin{array}{l}\text { F3 CSR has a positive direct significant effect } \\
\text { on corporate image (effect size }=.23 \text { ) }\end{array}$ \\
\hline $\mathrm{H} 4$ & Image <- F4 CSR & .22 & $* * *$ & Reject & $\begin{array}{l}\text { F4 CSR has a positive direct significant effect } \\
\text { on corporate image (effect size }=.22 \text { ) }\end{array}$ \\
\hline $\mathrm{H} 5$ & FP <--- Image & .43 & $* * *$ & Reject & $\begin{array}{l}\text { Corporate image has a positive direct significant } \\
\text { effect on FP (effect size }=.43 \text { ) }\end{array}$ \\
\hline
\end{tabular}

***Correlation is significant at the 0.00 level; F1 CSR: CSR to society, natural environment, future generations, and NGOs; F2 CSR: CSR to employees; F3 CSR: CSR to customers; F4 CSR: CSR to the government; FP: financial performance.

Additionally, in examining the impact of F3 CSR (CSR to customers) on corporate image, there is evidence that F3 CSR has positive path coefficients and strong significant $\mathrm{P}$-values $(0.23 ; \mathrm{P}<0.001)$. This significant $\mathrm{P}$ value rejects the null hypothesis (estimates equals zero) and indicates that the corporate (hotel) image increases when the hotel provides full and accurate information about its products to their customers; the hotel respects consumer rights beyond the legal requirements; and the hotel pays great concern to customers' satisfaction. These results are in line with the findings of the studies conducted by Becker-Olsen et al., (2006), and Pérez \& Rodríguez del Bosque (2015).

Furthermore, the SEM results indicate F4 CSR (CSR to the government) has a direct and either positive significant impact $(0.22 ; \mathrm{P}<0.001)$ on corporate image. This highly significant $(\mathrm{P}<0.001)$ path coefficient provide an evidence to reject the null hypothesis (no relationship exists) and indicates F4 CSR has a positive direct effect on the corporate image. This result indicates that the corporate (hotel) image increases when the hotel always pays its taxes on a regular and continuing basis; and complies with legal regulations completely and promptly. This result is supported by several previous studies such as those conducted by Tapper (1997), and Mandina et al., (2014).

Finally, the study results declare that the hotel financial performance will be improved when its image increase. In other words, the SEM results indicate that hotel image has a direct positive significant impact (0.43; $\mathrm{P}<0.001)$ on financial performance. This highly significant $(\mathrm{P}<0.001)$ path coefficient provide an evidence to reject the null hypothesis (no relationship exists) and indicates that hotel image has a positive and direct effect on financial performance. The results also indicates the hotel financial performance (employees' productivity and revenue per 
room) will increase when the hotel has a superior brand advantage; brand awareness; brand image, and brand personality in comparison with its main direct competitors in the market. This is consistent with results of several previous studies, such as those conducted by Chung et al., (1999), Roberts and Dowling, (2002), Eberl and Schwaiger (2005), and Malik \&, Nadeem (2014).

Based on the above discussion, sometimes hotels starting to adopt CSR practices, but suddenly discontinue implementing these practices, due to it is high-costs which lays companies at an economic disadvantage in comparison to other less socially responsible firms ( this explain why some authors find that CSR negatively affects FP). Corporate Social Responsibility is not just a campaign for public relation or just an advertisement, it's much more complicated. It's a situation in which the hotel is restructuring its environment to build a strong image that can generate better financial performance. In other words, CSR can generate FP after improving the hotel image.

\section{Conclusion}

This study sought to investigate the impact of corporate social responsibility (CSR) on financial performance (FP) through the mediating role of corporate image in the Egyptian hotel industry. The instrumental theories of CSR supported by Friedman (1970), Jensen (2000), and Porter and Kramer (2002), considered CSR as a means, which organizations employed to gain more profit, and its social practices are only a means to attain economic results. Despite the important theoretical role of CSR in improving business performance, fewer empirical studies have been carried out within the context of the service industry. Among those studies that investigate the impact of CSR on business performance, there is a lack of clarity concerning the dimensional structure of CSR, which CSR practices can enhance business performance, and whether the relationship between CSR and FP is positive, negative, direct or indirect through other mediating variables. It has therefore been recommended that this relationship (CSR and FP) should be tested further within a particular context (Chand, 2006) and that mediating variables should be taken into account for further examination of this link (Rowley and Berman, 2013).

Turker (2009) CSR scale was used in the current study to operationalize CSR. This scale contains four factors: First factor: including CSR to society, natural environment, future generations, and NGOs; Second factor: including CSR to employees; Third factor: including CSR to customers; Fourth factor: including CSR to the government. Three items were used to measure the hotel corporate image position (branding advantage) in the market (brand awareness, brand image, and brand personality) in comparison with its main direct competitors, mainly drawn from the study of Zou et al., (2003). Financial performance is measured in this study using two objective indicators (employee productivity and revenue per room)

This study data was obtained from surveying 360 four and five-star hotels in Egypt to test the impact of CSR on FP. A total of 320 responses (130 from five-star hotels and 190 from four-star hotels) were acquired. Twenty uncompleted questionnaires were removed leaving 300 usable questionnaires and yielding a response rate of $83 \%$. All questionnaires were completed by the hotels' general managers. The internal consistency (reliability) of the research variables were tested using Cronbach's alpha method, exploratory factor analysis (EFA) was employed to test the dimensionality of the research variables, and finally, structural equation modeling (SEM) was employed to test the research hypotheses.

Prior to testing the current study models; the dimensional structure of CSR was first examined. All the indicators employed to measure CSR were subjected to exploratory factor analysis (EFA) in SPSS, to find out how many factors they suggest. EFA produced a four-factor solution, representing CSR to society, natural environment, future generations, and NGOs; Second factor: including CSR to employees; Third factor: including CSR to customers; Fourth factor: including CSR to the government. These results give evidence that CSR can be employed in the current study as a multidimensional construct. Therefore, the models (see figure 1) that test the relationship between CSR (as a uni-dimensional construct) directly with FP or indirectly through corporate image, was neglected.

Two more models were proposed and tested in the current study using SEM as the main data analysis technique. The first model (see figure 2) test the relationship between CSR (as a multidimensional construct) directly with financial performance. The other model (see figure 3) investigated the relationship between CSR and FP indirectly through the mediating role of corporate image. The goodness of fit indices (GOF), as shown in table 3, indicate that model 3 (see figure 2) does not fit the data well while model 4 (see figure 3) perfectly fits the data. These results indicate that CSR practices cannot directly improve financial performance, but indirectly through the corporate image. 
To conclude, despite the apparent contradiction in the literature review regarding the nature of the relationship between CSR and financial performance, where some authors such as Hamilton et al., (1993); Diltz, 1(995a,b); Guerard, (1996); Kurtz and diBartolomeo, (1996); Reyes and Grieb, (1998); Statman, (2000); Baue et al., (2005) did not support the existence of direct relationship between CSR and financial performance, others such as Wood (1991), Vance (1975), Aupperle et al., (1985), and Ho Kang et al., (2010) claimed that CSR negatively affects financial performance. However, a third group of authors such as, Luck and Pilotte (1993), Diltz et al., (1999), Schueth (2003), Lee et al., (2013), Mustafa et al., (2012), Tamajón and Aulet (2013) argued that CSR positively affects financial performance. The current study results can explain this contradiction at least in one sense: that is in the role of corporate image as a mediating variable. Indeed, the current study results (based on employing SEM as the main data analysis technique) gives evidence that CSR cannot directly improve financial performance but should first enhance the corporate (hotel) image and then improve financial performance. This result might convince hotels managers (and other managers in similar industries) to implement CSR practices to first improve the hotel's image and then gain better financial performance.

\section{References}

- Aupperle, K.E., Carroll, A.B., Hatfield, J.D., (1985). An empirical examination of the relationship between corporate social responsibility and profitability. Academy of Management Journal 28 (2), 446-463.

- Ayuso, S., (2006). Adoption of voluntary environmental tools for sustainable tourism: analyzing the experience of Spanish hotels. Corporate Social Responsibility and Environmental Management 13, 207-220.

- Bagozzi, R. P. \& Yi, Y. (1988). On the Evaluation of Structural Equation Models. Journal of the Academy of Marketing Science, 16 (4). pp. 74-94.

- Barnett, M.L., Salomon, R.M., (2006). Beyond dichotomy: the curvilinear relationship between social responsibility and financial performance. Strategic of Management Journal 27 (11).

- Baue et al. (2005). International evidence on ethical mutual fund performance and investment style, Journal of Banking and Finance, Vo. 29 pp. 1751-1767

- Bauman C., Skitka, L. (2012). Corporate social responsibility as a source of employee satisfaction, Research in Organizational Behavior, Volume 32, pp.63-86.

- Becker-Olsen, K.L., Cudmore, B.A., Hill, R.P., 2006. The impact of perceived corporate social responsibility on consumer behaviour. J. Bus. Res. 59 (1), 46-53.

- Bhattacharya, C. Band, Sen, S., (2004). Consumer-company identification: a framework for understanding consumers' relationships with companies. Journal of Marketing 67 (2), 76-88

- Bohdanowicz, P., \& Zientara, P. (2009). Hotel companies' contribution to improving the quality of life of local communities and the well-being of their employees. Tourism and Hospitality Research, 9(2), 147-158

- Bowen, H.R. (1953), Social Responsibilities of the Businessman, Harper \& Row, New York, NY

- Bryman, A. and Bell, E. (2003). Business research methods. New York: Oxford University Press.

- Byrne, B. (2010). Structural Equation Modelling: Basic Concepts, Applications, and Programming. London: Lawrence Erlbaum Associates.

- Garriga, E. \& Melé, D. (2004). Corporate social responsibility theories: Mapping the territory. Journal of Business Ethics, 53 (1-2):51-71.

- Chand, M. (2006). The relationship between corporate social performance and corporate financial performance: Industry type as boundary condition. The Business Review, Cambridge, 5 (1), 240-245.

- Chung, L.H., Parker, L.D., 2010. Managing social and environmental action and accountability in the hospitality industry: a Singapore perspective. Accounting Forum 34 (1), 46-53.

- Chung, S.Y., Eneroth, K., \& Schneeweis, T. (April 1999). Corporate Reputation and Investment Performance: The UK and US Experience (Electronic version). Social Science Research Network (SSRN). [Accessed Online], Available (October 3, 2014)

- Clark, S. (2006). Corporate social responsibility: A marketing tool for major hotel brands. HSMAI Marketing Review, 23(1), 42-45

- Clarkson, M. B. E. (1995). A stakeholder framework for analyzing and evaluating corporate social performance. Academy of Management Review, 20(1), 92e117.

- Collis, J. \& HUSSY, R. 2003. Business Research: A Practical Guide for Undergraduate and Postgraduate Students. Palgrave: Macmillan.

- Davis, K.: (1973), 'The Case For and Against Business Assumption of Social Responsibilities', Academy of Management Journal16, 312-322.

- Deephouse, D.L., (1996). Does isomorphism legitimate? Academy of Management Journal 39 (4), 1024-1039. 
- Diltz et al. (1999). The performance of socially responsible mutual funds: incorporating sociopolitical information in portfolio selection, Managerial Finance, Vol. 23 pp. 29

- Diltz, J. D. (1995). The private cost of socially responsible investing. Applied Financial Economics 5: 69-77.

- Eberl, M. and Schwaiger, M. (2005). Corporate reputation: disentangling the effects on financial performance. European Journal of Marketing, 39, 7/8, 838-854.

- Fombrun, C., \& Shanley, M. (1990). What's in a name? Reputation building and corporate strategy. Academy of Management Journal, 33(2): 233-258.

- Font, X., Walmsley, A., Cogotti, S., McCombes, L., Häusler, N., (2012). Corporate social responsibility: the disclosure-performance gap. Tourism Management 33 (6), 1544-1553.

- Friedman, M. (1970). The social responsibility of business is to increase its profits. The New York Times Magazine

- Godfrey, P. C., \& Hatch, N. W. (2007). Researching corporate social responsibility: an agenda for the 21 st century. Journal of Business Ethics, 70,87e98.

- De Grosbois, D. (2012). Corporate social responsibility reporting by the global hotel industry: Commitment, initiatives and performance. International Journal of Hospitality Management, 31(3), 896-905.

- Guerard, J. (1996). Is there a cost to being socially responsible? Journal of Investing 5(2): 11-18.

- Hair, J., Black, B., Babin, B., Ralph, A. \& Ronald, T. (2006). Multivariate Data Analysis. 6th ed. London: PrenticeHall.

- Hamilton, D.L., Huffman, L.J., (1971). Generality of impression formation processes for evaluative and nonevaluative judgments. Journal of Personality and Social Psychology 20 (2), 200-207

- Hayward, R (2005) Maintaining Corporate Image. Prentice Hall.

- Hillman, A. J., \& Keim, G. D. (2001). Shareholder value, stakeholder management, and social issues: what's the bottom line? Strategic Management Journal, 22, 125e139

- Ho Kang, K. Lee, S. \& Huh, C. (2010). Impacts of positive and negative corporate social responsibility activities on company performance in the hospitality industry, International Journal of Hospitality Management 29, 72-82

- Holcomb, J.L., Upchurch,R.S., Okumus, F., (2007). Corporate social responsibility: what are top hotel companies reporting? International Journal of Contemporary Hospitality Management 19 (6), 461-475

- Husted, B. W., and D. B. Allen: (2000). 'Is It Ethical to Use Ethics as Strategy?',Journal of Business Ethics 27(1-2), 21-32.

- Kang, K. H., Lee, S., \& Huh, C. (2010). Impacts of positive and negative corporate social responsibility activities on company performance in the hospitality industry.International Journal of Hospitality Management, 29(1), 72-82

- Kirk, D. (1995). Environmental management in hotels.International Journal of Contemporary Hospitality Management, 7(6), 3-8.

- Kurtz, L., and DiBartolomeo, D. (1996) socially screened portfolios: An attribution analysis of relative performance. Journal of Investing 5(3): 35-41.

- Lee, E.M., S.-Y. Park and H.J. Lee, (2013). Employee perception of CSR activities: Its antecedents and consequences. Journal of Business Research, 66(10): 1716-1724.

- Luck, C., \& Pilotte, N. (1993). Domini Social Index performance. Journal of Investing, Fall: 60-62

- Malhotra, N. (2010). Marketing Research: An Applied orientation. Boston, Mass.: London: Pearson.

- Malik, M. and, Nadeem, M. (2014). Impact of corporate social responsibility on the financial performance of banks in Pakistan International Letters of Social and Humanistic Sciences Vol. 21, pp 9-19

- Mandina S.P. , Maravire C., and Masere V. (2014). Effectiveness of Corporate Social Responsibility in Enhancing Company Image, Journal of Applied Business and Economics vol. 16(3)

- McWilliams, A., \& Siegel, D. (2000). Corporate social responsibility and financial performance: correlation or misspecification?Strategic Management Journal, 21 (5), 603e609.

- Mitchell, R. K., B. R. Agle and D. J. Wood: (1997). 'Toward a Theory of Stakeholder Identification and Salience: Defining the Principle of Who and What Really Counts',Academy of Management Review 22(4), 853-886.

- Mustafa, S. A., Othman, A. R., \&Perumal, S. (2012). Corporate Social Responsibility and Company Performance in the Malaysian Context. Procedia-Social and Behavioral Sciences, 65, 897-905.

- Nunnally, J. C. 1967.Psychometric Theory. New York: McGraw Hill.

- Ogden, S. and Watson, R (1999). 'Corporate Performance and Stakeholder Management: Balancing Shareholder and Customer Interests in the U.K. Privatized Water Industry’,Academy of Management Journal42(5), 526-538

- Pallant, J. (2007). SPSS Survival Manual. Open University Press, Maideuhead, Berkshire.

- Park, S., \& Lee, S. (2009). Financial rewards for social responsibility: a mixed picture for restaurant companies. Cornell Hospitability Quarterly, 50(2), 168e179.

- Pérez, A. \& Rodríguez del Bosque, I. (2015). How0 customers construct corporate social responsibility images: Testing the moderating role of demographic characteristics, BRQ Business Research Quarterly 18(2), 127-141 
- Porter, M. E., \& Kramer, M. R. (2006). Strategy \& society: The link between competitive advantage and corporate social responsibility.Harvard Business Review,1-14 European Commission (2010)

- Punch, K . (2005). Introduction to social research: quantitative and qualitative approaches. London: Sage Publications.

- Redford, K. (2005). Business brains get a heart. Caterer \& Hotelkeeper, 195(4392), 36-39.

- Reyes, M. G., \& Grieb, T. (1998). The external performance of socially responsible mutual funds. American Business Review, 16: 1-7.

- Riordan, C. M., Gatewood, R. D., \& Bill, J. B. (1997). Corporate image: Employee reactions and implications for managing corporate social performance. Journal of Business Ethics, 16: 401-412

- Roberts, P. and Dowling, G. (2002). Corporate reputation and sustained superior financial performance. Strategic Management Journal, 23, 1077-1093.

- Rowley, T., Berman, S., (2013) A Brand New Brand of Corporate Social Performance, Business and Society, 39(4), pp. 397-418,

- Schueth, S. (2003). Socially Responsible Investing in the United States. Journal of Business Ethics, 43(3), 189-194.

- Schumacker, R. E. \& LomaX, R. G. (2010). A beginner's guide to structural equation modeling. London: The University of Alabama.

- Smith, W., and Higgins, M. (2000). 'Cause-Related Marketing: Ethics and the Ecstatic',Business and Society 39(3), 304-322

- Statman, M. (2000). Socially responsible mutual funds. Financial Analyst Journal, May/June, pp. 30 - 39.

- Tabachnick, B. \& Fidell, L. (2007). Using Multivariate Statistics. 5th ed. USA: Pearson Education.

- Tamajón L. G., Aulet X. i, (2013). Corporate social responsibility in tourism small and medium enterprises evidence from Europe and Latin America, Tourism Management Perspectives, Volume 7, July, Pages 38-46,

- Tapper R (1997). Voluntary Agreements for Environmental Performance Improvement - Perspectives on the chemical industry's Responsible Care program, Business Strategy and the Environment, Volume 6, pp287-292

- Turker, D. (2009). Measuring corporate social responsibility: A scale development study. J. Bus. Ethics, 85: 411427

- Vance, S. (1975). Are socially responsible corporations' good investment risks? Management Review 64 (8), 18-24

- Verschoor, C C. (2005) „Should All Companies Report on Their Corporate Responsibility? “ Strategic Finance, 87 (5), pp. 17-18.

- Waddock, S.A., and Graves, S.B. (1997). The corporate social performance-financial performance link. Strat. Manag. J., 18(4): 303-319

- Watts, P, \& Holme, L. (1999). Meeting Changing Expectations. Geneva: World Business Council For Sustainable Development

- WBCSD (1999). World Business Council for Sustainable Development. Corporate social Responsibility: Meeting Changing Expectations, Switzerland

- Wood, D.J., (1991). Corporate social performance revisited. Acad. Manag. Rev., 16: 691-718.

- Wu, M.L. (2006). Corporate social performance, corporate financial performance, and firm size: a meta-analysis. Journal of American Academy of Business 8 (1), 163-171

- Zou, S., Fang, E. and Zhao, S. (2003). The effect of export marketing capabilities on export performance: an investigation of Chinese exporters, Journal of International Marketing, Vol. 11 No. 4, pp. 32-55.

\section{الملخص العربي}

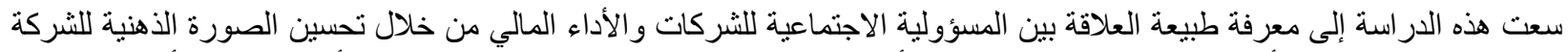

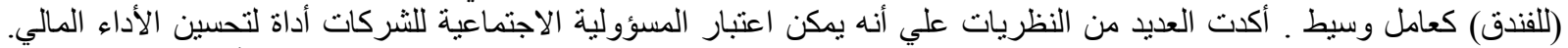

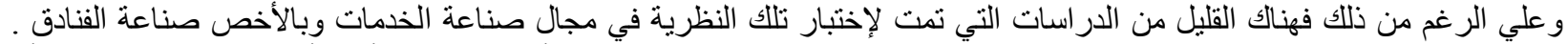

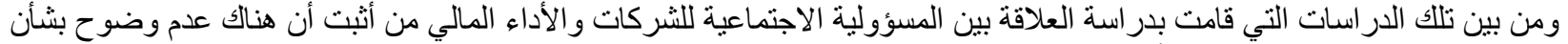

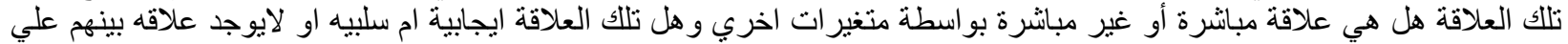

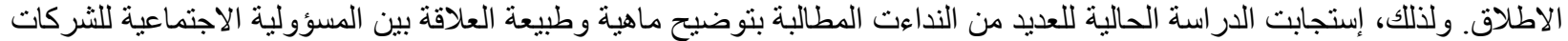

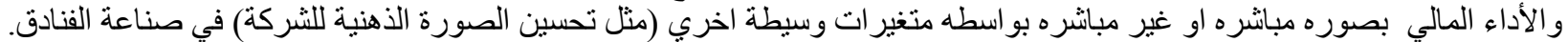

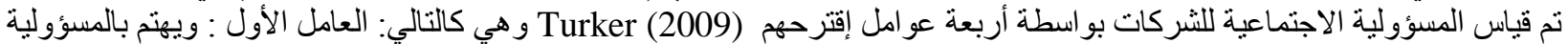

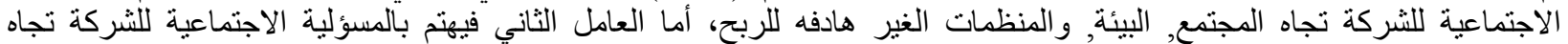

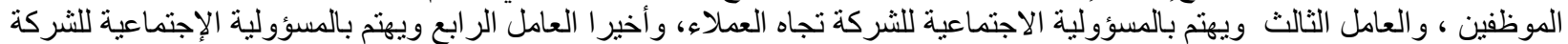
تجاه الملؤسسات الحكومية. كما تم قياس الأداء المالي بو اسطة بعض المقاييس الموضو عية مثل متوسط ربح غرفة الفندق ومنوسط إنتاجية 


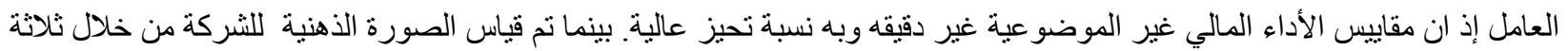
متعير ات إقترحهم (2003) و وهي الوعي بالغلامة التجارية، الصورة الذهنية للعلامة التجارية، وشخصية العلامة التجارية.

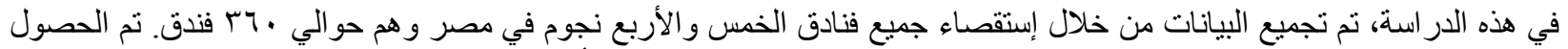

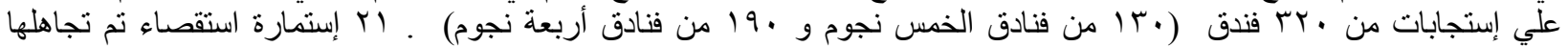

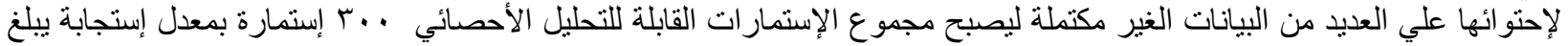

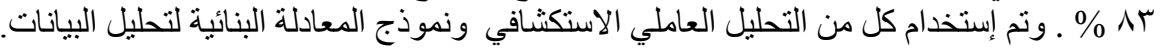

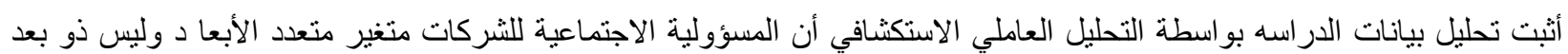

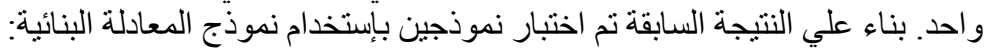

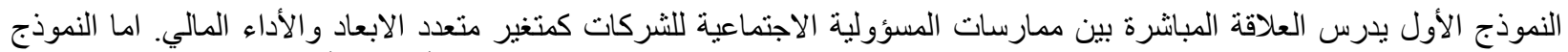

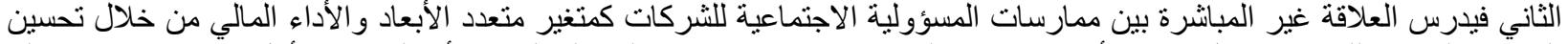

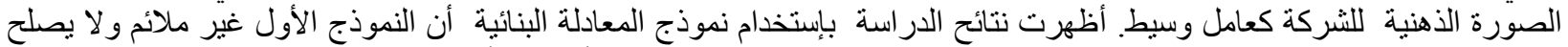
لتحليل العلاقة المبانرة بين ممارسات المسؤولية الاجتماعية للشركات كمتغير متعدد الأبعاد و الأداء المالي الني

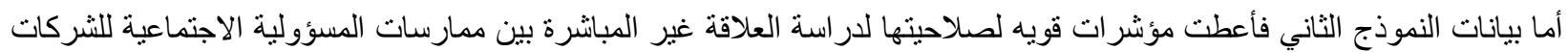

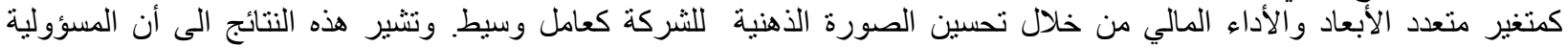

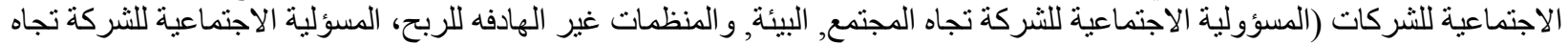

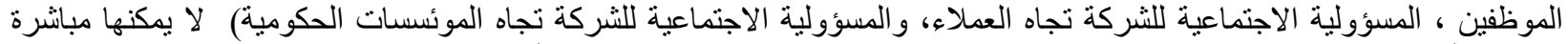

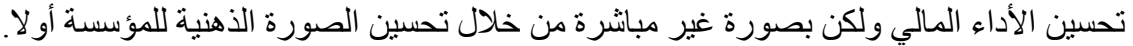

